\title{
Characterization of a Potyvirus Causing Mild Mosaic on Tuberose
}

\author{
C. C. Chen, Research Assistant, and C. A. Chang, Senior Plant Pathologist, Department of Plant Pathology, Tai- \\ wan Agricultural Research Institute, Wu-Feng, Taichung 413, Taiwan, Republic of China
}

\begin{abstract}
Chen, C. C., and Chang, C. A. 1998. Characterization of a potyvirus causing mild mosaic on tuberose. Plant Dis. 82:45-49.

A virus inducing mild mosaic symptoms on the leaves and peduncles of tuberose (Polianthes tuberosa) was isolated and partially characterized. The isolate, designated Tbr1, could be transmitted mechanically and by green peach aphids (Myzus persicae) in a non-persistent manner to tuberose seedlings but not to 16 common assay species. Flexuous rod-shaped particles with a mean length of $750 \mathrm{~nm}$ could be easily seen in infected leaf dips and in purified samples. Cytoplasmic cylindrical inclusions, pinwheel and laminated aggregates similar to those assigned to potyviral cylindrical inclusion type II, were observed in infected tuberose leaves. The purified capsid contained a single species of protein monomer with an estimated relative mass of 38 $\mathrm{kDa}$. In reciprocal sodium dodecyl sulfate-immunodiffusion tests, antiserum against Tbr1 reacted only with its homologous antigen but not with 22 different known potyviruses. Using primer pairs designed for potyvirus sequence amplification, a 2-kb DNA product equivalent to the estimated size for potyviruses was consistently amplified from purified Tbr1 virions or from crude infected tissue by reverse transcription polymerase chain reaction. On the basis of these results, Tbr1 was recognized as a unique species in the genus Potyvirus and hence designated as tuberose mild mosaic potyvirus (TMMV).
\end{abstract}

Additional keywords: virus identification

Tuberose (Polianthes tuberosa L.), a species native to Mexico, has been cultivated in Taiwan for over 300 years and has become an economically important ornamental bulb crop $(1,16,23,24,26)$. The major tuberose production areas in Taiwan are in Chiayi and Pintung counties, where the acreage is about 100 ha per year. Two types, namely "single petal" and "multipetal," are grown for perfume processing and cut flower production, respectively. Tuberose is subject to many pests and diseases including mites, flower thrips, scales, nematodes, Erwinia spp., Botrytis spp., and Sclerotium rolfsii (1). However, there has been only one partially characterized virus, possibly a potyvirus, described in New Zealand (15). During an extensive field survey in 1994 for tuberose diseases and pests in the major production areas in Taiwan, mild mosaic foliar symptoms were observed on most tuberose plants. This paper provides evidence on the biological, serological, and genome sequence properties of the putative viral agent and shows its relationship to potyviruses.

Corresponding author: C. A. Chang
E-mail: cachang@ms1.hinet.net

Accepted for publication 19 September 1997.

Publication no. D-1997-1112-01R

(C) 1998 The American Phytopathological Society

\section{MATERIALS AND METHODS}

Virus source and maintenance. The multipetal tuberoses, which exhibited mild mosaic symptoms on leaves, were collected from Chiayi County. Infected bulbs were planted in sterilized soil in a growth chamber at $25^{\circ} \mathrm{C}$ to allow further vegetative growth for subsequent studies. For long-term storage of virus culture, diseased bulbs and leaf samples were stored at $5^{\circ} \mathrm{C}$ and in $50 \%$ glycerol at $20^{\circ} \mathrm{C}$, respectively. An isolate (Tbr1) was maintained and used as a stock culture for characterization studies. Three other isolates (Tbr2, 3, and 4) collected from different localities were used for serological comparison tests.

Host range tests. Host range trials were conducted by mechanical inoculation. At least five plants of each species or cultivar were tested. Inoculum was prepared by grinding symptomatic leaves in potassium phosphate buffer (50 mM, pH 7.5). Inoculated plants were placed in an insect-proof screenhouse for at least 1 month for observation of disease development. Successful inoculation was determined by symptom expression and serological tests.

Aphid transmission tests. Seedlings of "single-petal" tuberose about 2 months after seed germination were used as test plants. Transmission trials were conducted with green peach aphids (Myzus persicae Sulzer) as previously described (5). Aphids were starved for 3-4 h before they were transferred onto the diseased tuberose leaves for a 30-min access feeding. Groups of 10 aphids were subsequently transferred to each tuberose seedling. Aphids were killed with insecticide on the second day and the test plants were kept in a screenhouse for observation. A total of 20 seedlings were used for the transmission test. For control experiments, five tuberose seedlings were treated similarly, but the vector aphids were not allowed access feeding on diseased plants.

Electron and light microscopy. Epidermal strips of healthy and infected tuberose leaves were treated by Triton X-100, stained either with calcomine orange and "Luxol" brilliant green (O-G) or Azure A followed by mounting in LR white resin and examined by light microscopy for viral inclusion bodies $(10,17)$. Virus particles from infected leaf dips or purified samples were negatively stained with $2 \%$ uranyl acetate $(\mathrm{pH} 4.2)$ and examined with a JOEL 200CX electron microscope (11). Preparation of ultrathin sectioned diseased leaf tissues and observation with transmission electron microscopy was performed as previously described $(9,27)$.

Virus purification. Tuberose leaves showing pronounced mild mosaic symptoms collected from the first flush leaves of diseased tuberose bulbs after 1 month of growth in a $25^{\circ} \mathrm{C}$ growth chamber were used for purification of Tbrl virions. The leaves were homogenized in a blender for 3 min with $2 \mathrm{ml}$ of potassium phosphate buffer $(500 \mathrm{mM}, \mathrm{pH} 7.5$, containing 10 $\mathrm{mM} \quad \mathrm{Na}_{2}$ EDTA, $1 \%$ [v/v] 2-mercaptoethanol and $0.25 \%[\mathrm{w} / \mathrm{v}] \mathrm{Na}_{2} \mathrm{SO}_{3}$ ), and 1 $\mathrm{ml}$ of chloroform and carbon tetrachloride (1:1) per gram of tissue. The homogenate was clarified by low-speed centrifugation $(3,500 \times g, 5 \mathrm{~min})$, and the supernatant was filtered through two layers of cheesecloth. The filtrate was stirred at $4^{\circ} \mathrm{C}$ for $1 \mathrm{~h}$ with the addition of $2 \%(\mathrm{w} / \mathrm{v})$ Triton X-100, followed by two cycles of differential centrifugation $(13,200 \times g$ for $10 \mathrm{~min}$ and $85,000 \times g$ for $1.5 \mathrm{~h})$. The pellet was resuspended in HEPES buffer $(20 \mathrm{mM}$, pH7.5, containing $10 \mathrm{mM} \mathrm{Na} 2$ EDTA) and subjected to equilibrium centrifugation in cesium sulfate as previously described (5). Virions in the opalescent zone were collected, diluted with HEPES buffer (20 $\mathrm{mM}, \mathrm{pH}$ 7.5), and concentrated to an optimum volume by a cycle of differential centrifugation as described above. The yield of purified virions was determined by reading the optical density of the sample at $260 \mathrm{~nm}$ by a spectrophotometer and calculated based on an assumed extinction coefficient of 2.4 without light scattering correction (14). 
Polyacrylamide gel electrophoresis of virion protein. Purified virus samples were treated with an equal volume of dissociation buffer and analyzed by discontinuous sodium dodecyl sulfate (SDS)polyacrylamide gel electrophoresis as described by Laemmli (18).

Antiserum preparation and serological tests. Antiserum against Tbr 1 was prepared by immunizing New Zealand white rabbit intramuscularly as previously described $(5,6)$. One milligram of purified virion was given in each injection and a total of four consecutive injections were administered at weekly intervals. Immunized rabbits were bled weekly 1 week after the last injection. Antisera collected 1-3 months after the last injection were used for serological studies. Serological relationships of Tbr1 with 24 known potyviruses were determined by reciprocal SDS-immunodiffusion tests as described by Purcifull and Batchelor (21). Antisera and SDS-treated antigens of the following potyviruses were used in this study: bean common mosaic (BCMV) (2); blackeye cowpea mosaic (BlCMV) (2); L (2), Scott (2), PV2 (6), and G (19) isolates of bean yellow mosaic (BYMV); clover yellow vein (CYVV) (6); TP1 isolate of lily mottle virus (LiMV) (4); passionfruit mottle (PaMV) (3); passionfruit crinkle (PCV) (7); papaya ringspot virus (PRV-W) (22); pea seed-borne mosaic (PSbMV) (5); Ts isolate of peanut stripe (PStV) (8); potato virus Y (PVY) (21); passionfriut woodiness (PWV) (3); soybean mosaic (SMV) (2); turnip mosaic virus (TuMV); water- melon mosaic virus 2 (WMV-2) (22); and zucchini yellow mosaic virus (ZYMV) (20). A broad spectrum monoclonal antibody reacting with potyviruses was purchased from Agdia Inc. (Elkhart, IN) and used in indirect ELISA to react with Tbr1. Two potyvirus isolates from amaryllis and oriental narcissus, presumably hippeastrum mosaic (HiMV) and narcissus yellow stripe (NYSV) potyviruses and an unidentified potyvirus from Lycoris aurea Herb. (LPV) were also used for comparison.

RNA extraction and reverse transcription-polymerase chain reaction (RT-PCR). Viral RNA of Tbr1 was isolated from purified virions $(1 \mathrm{mg} / \mathrm{ml})$ by disruption with $1 / 10$ volume of $40 \mathrm{mM}$ Tris-HCl buffer, $\mathrm{pH} 7.8$, containing $20 \mathrm{mM}$ NaOAC, 1 mM EDTA, and 1\% (w/v) SDS, extraction with phenol/chloroform, RNA precipitation with ethanol and resuspension in $20 \mu \mathrm{l}$ of sterilized water. The first strand of cDNA was synthesized from the viral RNA by a cDNA synthesis kit (Stratagene, La Jolla, CA) with the addition of an oligodT primer. Subsequently, one set of potyvirus specific primers (28), was used to PCR-amplify the sequences covering the entire coat protein and part of the nuclear inclusion $\mathrm{b}$ regions of the Tbr1 genome. Super Taq polymerase (Invitrogen, Carlsbad, CA) was used in the amplification reaction for 26 cycles (Perkin Elmer GeneAmp system 2400) as the following program: denaturing at $94^{\circ} \mathrm{C}$ for $1 \mathrm{~min}$, annealing at $60^{\circ} \mathrm{C}$ for $30 \mathrm{~s}$, and DNA synthesis at $72^{\circ} \mathrm{C}$ for $2 \mathrm{~min}$. An elongation step at $72^{\circ} \mathrm{C}$ for $10 \mathrm{~min}$ was performed at
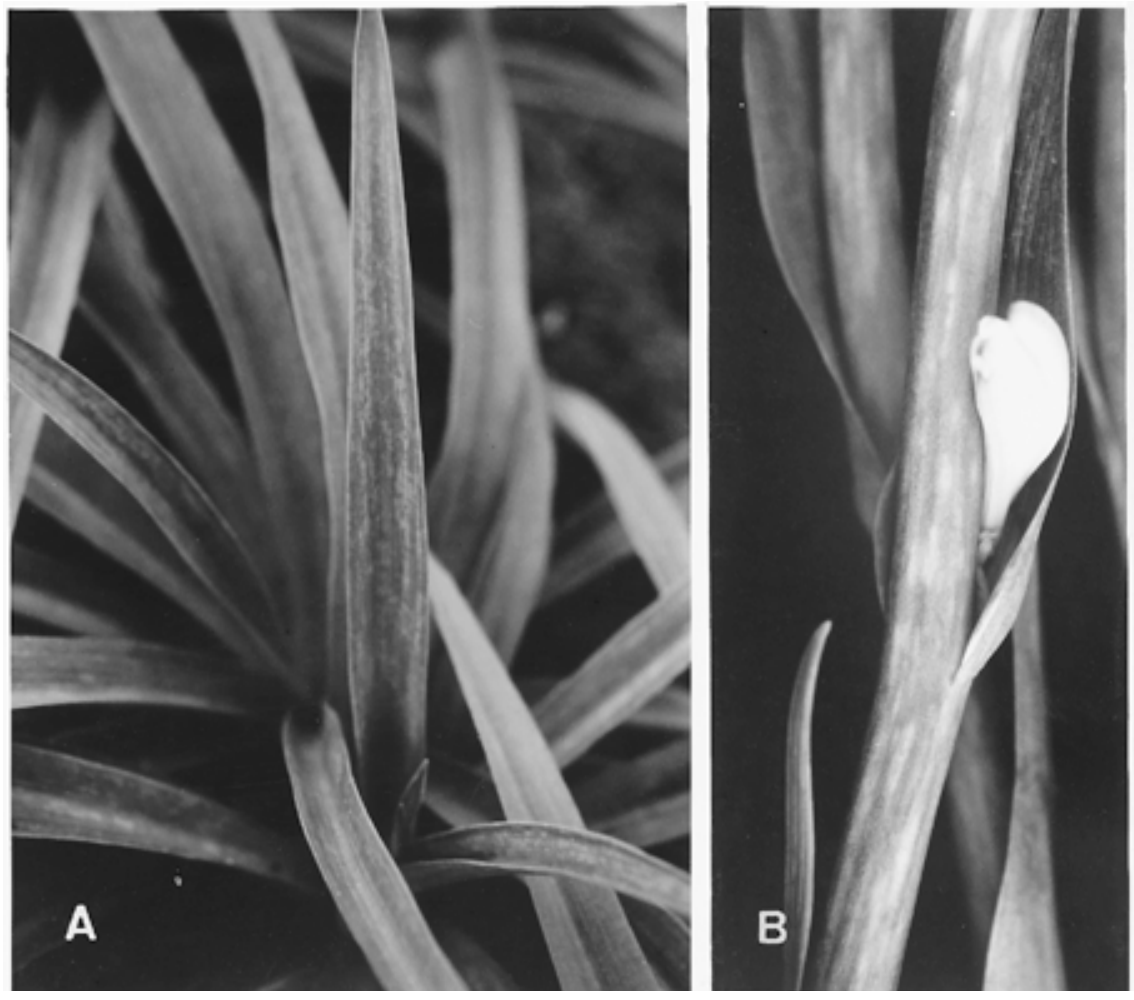

Fig. 1. Mild mosaic symptoms induced by tuberose mild mosaic virus observed on field plants. (A) symptoms on leaves; (B) symptoms on peduncles. the last cycle. Tulip breaking potyvirus (12) was used for positive control in RTPCR experiment, and the amplification products were analyzed by electrophoresis in a $1 \%$ agarose gel.

\section{RESULTS}

Host range and symptomatology. One month after mechanical inoculation, 15 out of 25 seedlings of the "single-petal" tuberose developed conspicuous mild mosaic foliar symptoms that were indistinguishable from those observed on the field plants (Fig. 1). Successful inoculations were further confirmed by positive reactions to the antiserum against Tbr1 in ELISA tests. No visible symptoms or positive reactions to antisera against Tbr1 in ELISA test were found with any of the following plant species: Chenopodium amaranticolor Coste and Reyn, C. quinoa Willd., Gomphrena globosa L., Nicotiana benthaminana Domin, N. tabacum L.
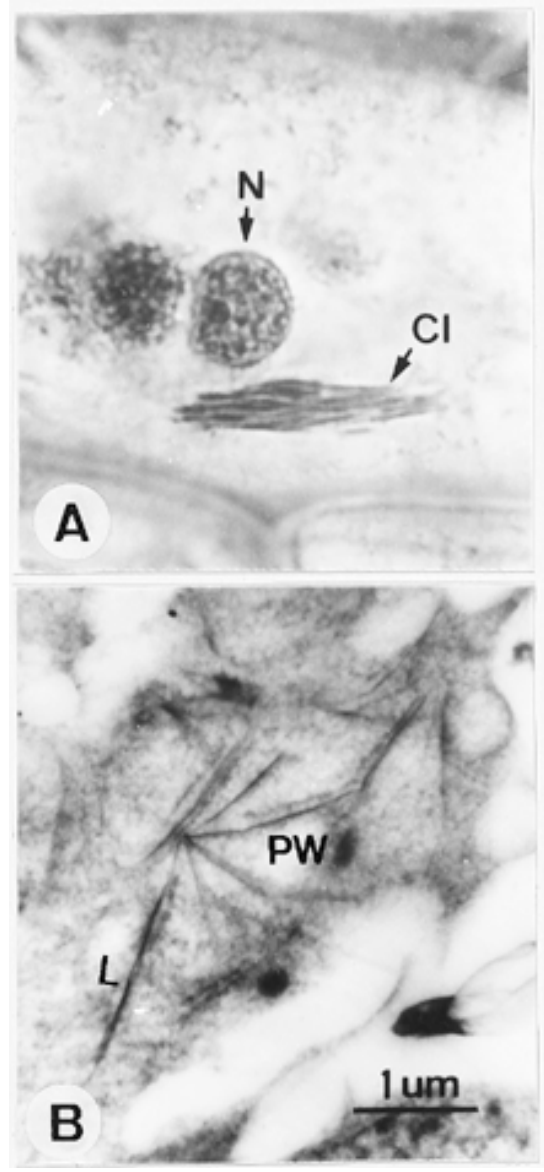

Fig. 2. Light and electron micrographs of cylindrical inclusions induced by tuberose mild mosaic virus. (A) light micrograph of epidermal tissue of tuberose stained with luxol brilliant green and calcomine orange. Straight and bundled shaped aggregates of cylindrical inclusions (CI) accumulated beside the nucleus (N) in epidermal cells of tuberose. (B) pinwheel structure (PW) of cylindrical inclusions with straight arms and laminated aggregates (L) were consistently observed in cytoplasm of tuberose cell. 
'White burley', N. glutinosa L., N. debnyii domin, Lycopersicon esculentum Mill. 'Farmers 301', Capsicum annuum L. cv. 'Blue-Star', Datura metal L., D. stramonium L., Nicandra physaloides, Physalis floridana, Pisum sativum L., Vigna unguiculata subsp. sesqeipedalis (L.) Verdc., and Cucumis sativus L.

Aphid transmission tests. Two out of 20 tuberose seedlings, but none of the five control plants, developed typical symptoms and showed positive reaction to Tbr1 antiserum in ELISA 10 days after aphid transmission.

Light and electron microscopy. Cytoplasmic cylindrical inclusions (CIs) were consistently observed in Tbr1-infected epidermal cells processed by $\mathrm{O}-\mathrm{G}$ staining. These CIs were seen as parallel arrangement of short bundles similar to those frequently found in potyvirus-induced CIs (Fig. 2A). In electron microscopy, flexuous rod-shaped particles were readily detected in negatively stained leaf dips and in purified virion preparations. The mean length of 110 particles was $750 \mathrm{~nm}$. In ultrathin-sectioned infected cells, pinwheel and laminated but not scroll-like inclusions were detected in cytoplasm (Fig. 2B). The pinwheel inclusions were consistently seen as straight arms with laminated aggregates very similar to the type II cylindrical inclusions induced by lettuce mosaic potyvirus (13). Therefore, it was concluded that Tbr 1 should fall into the Subdivision II of the Potyviridae based on Edwardson's classification (13).

Virus purification and antiserum preparation. Several attempts failed to purify Tbr1 from diseased leaf tissue collected directly from the fields following the procedures as described above. No visible bands were found after equilibrium centrifugation, although some virus particles could be observed by electron microscopy in the partially purified samples. Subsequently, infected tuberose bulbs were grown in a growth chamber with constant temperature at $25^{\circ} \mathrm{C}$. The first flush of leaves was harvested from these bulbs for purification and provided a satisfactory yield of virions. The purified virion samples had an ultraviolet absorption spectrum typical of potyviruses (25), and an absorption ratio (260:280) of 1.24. Assuming an extinction coefficient of 2.4 as potyviruses, the yield of purified Tbrl virions was about $1 \mathrm{mg} / \mathrm{kg}$ of infected tuberose tissue. Analysis of the purified samples in $12 \%$ polyacrylamide gels gave only one species of protein monomer with an estimated relative mass $\left(M_{\mathrm{r}}\right)$ of $38 \mathrm{kDa}$ (Fig. 3). No other contaminating proteins could be resolved in the analyzing gels. Tuberose leaves without any visible symptoms were used as controls and subjected to the same purification procedures. No virus particles and nor any Tbr1 equivalent protein species were detected by electron microscopy or polyacrylamide gel electrophoresis, respectively (Fig. 3, lane 2).
Serology. A polyclonal antiserum against purified Tbr1 virions was prepared in this study. The antiserum reacted strongly with its homologous antigen but not with healthy tuberose tissue in a SDSimmunodiffusion test (Fig. 4) and ELISA (Table 1). The potyvirus group-specific monoclonal antibody also reacted with Tbr1 in indirect ELISA (data not shown). In reciprocal SDS-immunodiffusion tests, Tbr1 antiserum reacted strongly with its own homologous antigen but not with the following potyviruses: BCMV, BlCMV, BYMV-L, BYMV-Scott, BYMV-PV2 and BYMV-G, CYVV, LiMV-TP1, PaMV, PCV, PRV-W, PSbMV, PStV-Ts, PVY, PWV, SMV, TuMV, WMV-2, and ZYMV. Reciprocally, none of the antisera against the above potyviruses reacted with Tbr1 antigen. In antigen-coating ELISA (indirect type) Tbr1 antiserum reacted with antigens of BYMV, CYVV, LMoV-TP1, PaMV, PMoV, PRV-W, PStV, PVY, TBVFa, TuMV, and ZYMV, but the heterologous ELISA readings were significantly lower than the homologous ones except for PVY, PRV-W, ZYMV, and a potyvirus isolate from oriental narcissus (Table 1). However, in double-sandwiched ELISA (direct type), Tbr1 antiserum reacted only with its homologous antigen but not with any of the 25 different potyvirus antigens tested so far including those antigens which reacted in indirect ELISA (Table 1). This result, together with those obtained in SDS-immunodiffusion tests, strongly indi-

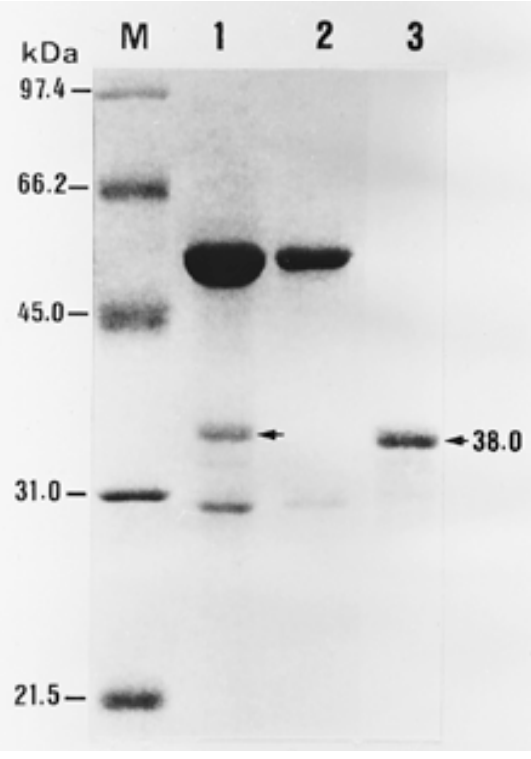

Fig. 3. Sodium dodecyl sulfate-polyacrylamide gel electrophoresis of capsid protein of tuberose mild mosaic virus (TMMV). Lane M, protein markers; Lanes 1 and 2 represent semipurified samples by two cycles of differential centrifugations $(13,200 \times g, 10 \mathrm{~min}$ and $85,000 \times g, 1.5$ h) of TMMV-infected and healthy control tuberose tissue, respectively; Lane 3, TMMV CP with estimated relative mass of $38 \mathrm{kDa}$ after further purifying the sample from lane 1 by equilibrium centrifugation. cated that although distantly related serologically to some of the known potyviruses, Tbr1 is a serologically unique member of potyviruses. After comparison of 12

Table 1. Cross-reactivities (absorbance at 405 $\mathrm{nm}^{\mathrm{a}}$ ) of antiserum against tuberose mild mosaic virus to 25 different potyviruses as determined by direct and indirect enzyme-linked immunosorbent assay (ELISA) ${ }^{\text {b }}$

\begin{tabular}{|c|c|c|c|c|}
\hline \multirow[b]{2}{*}{ Antigens $^{c}$} & \multicolumn{2}{|c|}{ Direct } & \multicolumn{2}{|c|}{ Indirect } \\
\hline & $50 \times$ & $100 x$ & $50 \times$ & $100 x$ \\
\hline TMMV & 1.77 & 1.15 & 1.11 & 1.21 \\
\hline BCMV & $-^{\mathrm{d}}$ & - & - & - \\
\hline BlCMV & - & - & - & - \\
\hline BYMV-G & - & - & - & - \\
\hline BYMV-L & - & - & 0.60 & - \\
\hline BYMV-PV2 & - & - & 0.93 & 0.70 \\
\hline BYMV-Scott & - & - & 1.35 & 0.71 \\
\hline CVMV & - & - & - & - \\
\hline CYVV & - & - & 0.46 & 0.39 \\
\hline HiMV & - & - & 0.33 & 0.45 \\
\hline LiMV-TP1 & - & - & 0.36 & - \\
\hline LPV & - & - & 0.55 & 0.62 \\
\hline NYSV & - & - & 1.04 & 1.29 \\
\hline PaMV & - & - & 0.51 & 0.52 \\
\hline PCV & - & - & - & - \\
\hline PMoV & - & - & 0.89 & 0.87 \\
\hline PRV-W & - & - & 1.04 & 1.01 \\
\hline PSbMV & - & - & - & - \\
\hline PStV & - & - & 0.65 & 0.45 \\
\hline PVY & - & - & 2.22 & 2.14 \\
\hline PWV & - & - & - & - \\
\hline SMV & - & - & - & - \\
\hline TBV-Fa & - & - & - & - \\
\hline TuMV & - & - & - & - \\
\hline WMV2 & - & - & - & - \\
\hline ZYMV & - & - & 0.96 & 0.81 \\
\hline Healthy control & - & - & - & - \\
\hline
\end{tabular}

a Absorbance values were an average of two replicate wells.

b Direct and indirect ELISA were conducted as described in the text. Immunoglobulin (IgG) at a concentration of $1 \mathrm{mg} / \mathrm{ml}$ purified from TMMV antiserum collected 1 month after the last immunization was used at a dilution of 1:1200 in both direct and indirect ELISA tests. Alkaline phosphatase conjugated TMMV IgG diluted 1:1200 and alkaline phosphatase conjugated goat anti-rabbit IgG (Jackson 111-055003 ) diluted 1:6000 were used in direct and indirect ELISA, respectively. In indirect ELISA virus infected tissues were ground in coating buffer, while in direct ELISA infected tissues were ground in $50 \mathrm{mM}$ phosphate buffer $(\mathrm{pH}$ 7.5 ) at a ratio of $10 \mathrm{ml} / \mathrm{g}$. The sap thus obtained was taken as $1 / 10$ dilution.

c $\mathrm{BCMV}=$ bean common mosaic; $\mathrm{BlCMV}=$ blackeye cowpea mosaic; BYMV = bean yellow mosaic; CVMV = chili veinal mottle; $\mathrm{CYVV}=$ clover yellow vein; $\mathrm{HiMV}=$ hippeastrum mosaic; LiMV-TP1 = TP1 isolate of lily mottle; LPV = an unidentified potyvirus isolate from Lycoris aurea; NYSV= narcissus yellow stripe; $\mathrm{PaMV}=$ passionfruit mottle; $\mathrm{PCV}=$ passionfruit crinkle; $\mathrm{PMoV}=$ peanut mottle; PRV-W = papaya ringspot; $\mathrm{PSbMV}=$ pea seed-borne mosaic; PStV $=$ Ts isolate of peanut stripe; $\mathrm{PVY}=$ potato virus $\mathrm{Y} ; \mathrm{PWV}=$ passionfruit woodiness; SMV= soybean mosaic; $\mathrm{TBV}-\mathrm{Fa}=\mathrm{Fa}$ isolate of tulip breaking; TuMV = turnip mosaic; WMV-2 = watermelon mosaic virus $2 ; \mathrm{ZYMV}=$ zucchini yellow mosaic.

d Negative reaction. 


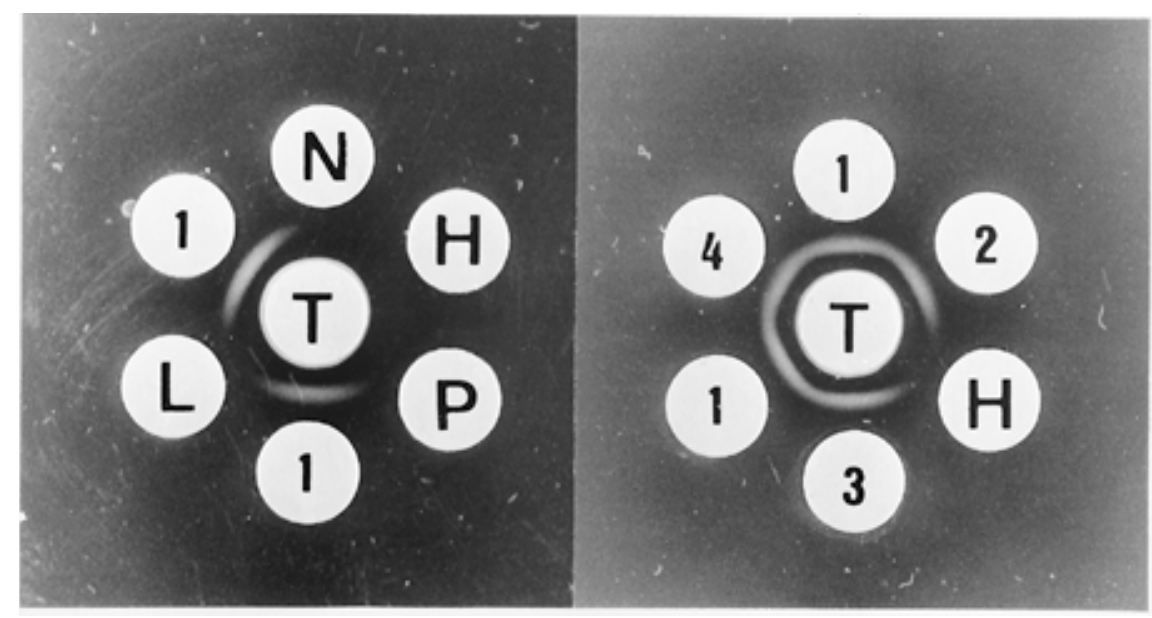

Fig. 4. Sodium dodecyl sulfate (SDS) immunodiffusion tests with several isolates of tuberose mild mosaic virus (TMMV), narcissus yellow stripe virus (NYSV), hippeastrum mosaic virus (HiMV) and a potyvirus isolate from Lycoris aurea in Taiwan. SDS-treated extracts of virus infected tissue were used as antigens to react with undiluted antiserum of TMMV (T). The peripheral wells were filled with antigens from healthy tuberose (H), NYSV infected narcissus (N), HiMV infected hippeastrum $(\mathrm{P})$, potyvirus isolates from $L$. aurea $(\mathrm{L})$, the type isolate (Tbr1) of TMMV (1), and isolates Tbr2 (2), Tbr3 (3), and Tbr4 (4) of TMMV obtained from different localities in Taiwan.

isolates collected from various counties in Taiwan, we were not able to find any serological differences among them in SDSimmunodiffusion (Fig. 4) or in ELISA tests.

PCR amplification. A DNA fragment about 2 -kb pairs in size could be consistently detected from purified Tbr1 virion samples or from crude infected tuberose tissue by running a potyvirus-specific RTPCR (Fig. 5). The size of the PCR product fell within the estimated range of potyvirus genome. No equivalent DNA product could be generated from uninfected tuberose tissue by the same procedure.

\section{DISCUSSION}

Based on the properties of Tbr1 in aphid transmissibility, particle size, and morphology, the ability to induce cytoplasmic cylindrical or pinwheel inclusions, serological cross reactivities to potyvirus group-specific monoclonal antibody and to some of the known potyviruses and the RNA sequence homology with potyvirus specific primer pairs in PCR, we propose tuberose mild mosaic virus (TMMV) as a species of the genus Potyvirus. To our knowledge, this is currently the most fully characterized virus found to infect tuberose. A virus isolated from tuberose with mottling symptoms was documented in New Zealand (15), which was thought to be a potyvirus on the basis of its particle size and morphology and the consistency of laminated cytoplasmic inclusions associated with diseased tissue. However, due to the lack of supporting evidence in serological and other biological properties, the identity of the New Zealand tuberose virus was not conclusive. Nevertheless, the New Zealand tuberose virus has similarities to TMMV in the symptoms induced on tuberose leaves and the morphology of pinwheel inclusions with similar long and

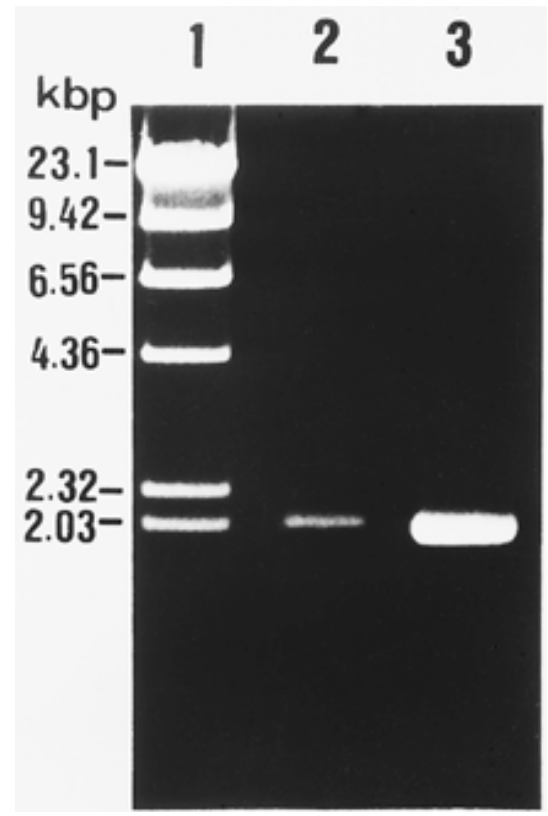

Fig. 5. Agarose gel electrophoresis of DNA products derived from reverse-transcription polymerase chain reaction (RT-PCR) of purified tuberose mild mosaic virus RNA using potyvirus-specific primers designed by Zerbini et al. (28). Lane 1, $\lambda$ DNA/Hind III markers; Lane 2, control product generated by the same RT-PCR procedure from RNA template of tulip breaking potyvirus; Lane 3, RT-PCR product with approximately $2 \mathrm{~kb}$ derived from purified TMMV RNA template.

peduncles of more than $90 \%$ of tuberose plants in the field, especially during cool temperature weather, its actual effects on the growth and vigor of the plant and the quality and yield of flower are still uncertain because of the lack of virus-free plants for comparison. This is a question that we urge our horticultural colleagues to examine. The answer could have important practical implications for tuberose production in Taiwan and possibly worldwide. have tested so far. Furthermore, TMMV was unable to infect all the test plants except tuberose and, to our knowledge, none of the other recognized members of potyviruses have been found capable of infecting tuberose. Therefore, it should be reasonable to conclude that TMMV is a new potyvirus that has never been fully described before.

In the early stage of our study, attempts to purify TMMV from tuberose leaves failed. In partially purified samples, flexuous rod-shaped particles could be seen but antiserum of acceptable quality was not obtainable. Fortunately, modification of sample preparation for purification as described in the text made a great difference in increasing the yield and hence the purity of virions. The same phenomenon has been consistently found in our experience in purifying viruses from ornamental plants where viruses are usually of low concentration in the diseased tissues compared to viruses from vegetable or other crops.

Although symptoms of TMMV could easily be observed on the leaves and

\section{ACKNOWLEDGMENTS}

This research was partly supported by funds from the Council of Agriculture of the Republic of China. We thank Ta-shiung Huang and Bor-shiun $\mathrm{Du}$, Department of Horticulture, National Chiayi Institute of Agriculture, Taiwan, R. O. C., for providing us with tuberose bulbs and seeds.

\section{LITERATURE CITED}

1. Benschop, M. 1993. Polianthes. Pages 589601 in: The Physiology of Flower Bulbs. A De Hertogh and M. Le Nard, eds. Elsevier, Amsterdam.

2. Chang, C. A. 1991. Virus diseases and their vectors of legume crops in Taiwan. Pages 99 110 in: Integrated Control of Plant Virus Diseases. 1991 FFTC Supplement No.1.

3. Chang, C. A. 1992. Characterization and comparison of passionfruit mottle virus, a newly recognized potyvirus, with passionfruit woodiness virus. Phytopathology 82:13581363

4. Chang, C. A., Chen, C. C., and Tsai, H. T. 1995. Characterization and purification of a virus isolate inducing lily mottling. Plant Prot. Bull. 37:446.

5. Chang, C. A., Chen, C. M., Chen, H. C., Deng, T. C., and Huang, C. H. 1989. Pea 
seed-borne mosaic virus causing pea mottling in Taiwan. Plant Prot. Bull. 31:366-376.

6. Chang, C. A., Hiebert, E., and Purcifull, D. E. 1988. Purification, characterization, and immunological analysis of nuclear inclusions induced by bean yellow mosaic and clover yellow vein potyviruses. Phytopathology 78:1266-1275.

7. Chang, C. A., and Lin, H. H. 1989. Passionfruit crinkle virus, a new potyvirus isolated from passionfruit in Taiwan. Plant Prot. Bull 31:409-410.

8. Chang, C. A., Purcifull, D. E., and Zettler, F. W. 1990. Comparison of two strains of peanut stripe virus in Taiwan. Plant Dis. 74:593-596.

9. Chen, Y. K., and Chen, M. J. 1994. Lettuce leafroll mosaic_-A new lettuce disease caused by caulimovirus-like agent in Taiwan. Plant Pathol. Bull. 3(4):209-215.

10. Christie, R. G., and Edwardson, J. R. 1977. Light and electron microscopy of plant virus inclusions. Fla. Agric. Exp. Sta. Mongr. Ser. No. 9.155 pp.

11. Christie, S. R., Purcifull, D. E., Crawford, W. E., and Ahmed, N. A. 1987. Electron microscopy of negatively stained clarified viral concentrates obtained from small tissue samples with appendices on negative staining techniques. Fla. Agric. Exp. Sta. Tech. Bull. 872. $45 \mathrm{pp}$.

12. Deng, T. C., and Zettler, F. W. 1995. Incidence of three aphid-transmitted Lilium vi- ruses. Phytopathology 85:1137.

13. Edwardson, J. R., and Christie, R. G. 1996. Cylindrical Inclusions. Fla. Agric. Exp. Sta. Bull. No. 894. 79 pp.

14. Hollings, M., and Brunt, A. A. 1981. Potyvirus group. CMI/AAB Descriptions of Plant Viruses, No. 245.

15. Horner, M. B., and Person, M. N. 1988. Purification and electron microscopy studies of a probable potyvirus from Polianthes tuberosa L. J. Phytopathol. 122:261-266.

16. Huang, S. J. 1981. Study of dry heat bulb treatment on promotion of Polianthes tuberosa L. M.S. thesis. Research Institute of Horticulture, National Chung-Hsing University. $61 \mathrm{pp}$.

17. Ko, N. J., and Chen, M. J. 1982. Light and electron microscopy diagnosis for occurrence of dahlia mosaic virus in Taiwan. Plant Proc. Bull. 24:201-204.

18. Laemmli, U. K. 1970. Cleavage of structural proteins during the assembly of the head of bacteriophage T-4. Nature 227:680-685.

19. Nagel, J., Zettler, F. W., and Hiebert, E. 1983. Strains of bean yellow mosaic virus compared to clover yellow vein virus in relation to gladiolus production in Florida. Phytopathology 73:449-454.

20. Purcifull, D. E., Adlerz, W. C., Simone, G. W., Hiebert, E., and Christie, S. R. 1984. Serological relationships and partial characterization of zucchini yellow mosaic virus isolated from squash in Florida. Plant Dis.
68:230-233.

21. Purcifull, D. E., and Batchelor, D. L. 1977. Immunodiffusion tests with sodium dodecyl sulfate (SDS)-treated plant viruses and plant viral inclusions. Fla. Agric. Exp. Sta. Tech. Bull. 788.39 pp.

22. Purcifull, D. E., and Hiebert, E. 1979. Serological distinction of watermelon mosaic virus isolates. Phytopathology 69:112-116.

23. Shen, T. M., Huang, K. L., and Huang, T. S 1987. Study on hybridization and sexual propagation of tuberose. Pages 167-175 in: Symposium on the Improvement of Flower Production. Tau-Yuan Dis. Agric. Impro. Sta Taiwan, R. O. C.

24. Shen, T. M., Huang, T. S., Du, B. S., and Huang, K. L. 1993. Breeding of tuberose for cut flower. J. Chinese Soc. Hortic. Sci. 39(1):23-29.

25. Stace-Smith, R., and Tremaine, J. H. 1970 Purification and composition of potato virus Y. Phytopathology 60:1785-1789.

26. Trueblood, E. W. E. 1973. 'Omixochitl' the Tuberose (Polianthes tuberosa). Econ. Bot. 27:157-173.

27. Venable, J. H., and Coggeshall, R. 1965. A simplified lead citrate stain for use in electron microscopy. J. Cell Biol. 25:407-408.

28. Zerbini, F. M., Koike, S. T., and Gibertson, R. L. 1995. Biological and molecular characterization of lettuce mosaic potyvirus isolates from the Salinas Valley of California. Phytopathology 85:746-752. 